\title{
Carol Rittner and John K. Roth, Eds. Advancing Holocaust Studies
}

\author{
(New York: Routledge, 2021), softcover, xiii + 198 pp.
}

\author{
JOSEY G. FISHER \\ jfisher@gratz.edu \\ Gratz College, Melrose Park, PA 19027
}

Advancing Holocaust Studies is a riveting collection of essays by world-renowned scholars in the field, reflecting on both their personal journeys and the professional lenses through which they see their research, teaching, and writing. Through these individual voices, the reader is presented not only with the complexity of the field as it has evolved but indications about its future directions.

The collection is an outgrowth of a conference "Critical Junctures: Ethical Challenges of Holocaust Studies," held during United States Holocaust Memorial Museum's twenty-fifth anniversary observance in 2018. Conference coordinators Carol Rittner and John K. Roth later joined with eleven colleagues to explore further these issues and collaborate on this volume. The scholars include Alex Alvarez, Debórah Dwork, Robert P. Ericksen, Wolf Gruner, Sara R. Horowitz, Lisa Moses Leff, Edward T. Linenthal, Wendy Lower, Jonathan Petropoulos, Robert A. Ventresca, and James E. Young.

The editors' prologue prepares the reader for their unique approach, as you "meet authors who are like characters in a story. Learning and teaching about the Holocaust are the story; each of the book's contributors has a part in it" (8). Each scholar discusses a life experience that helps the reader to understand their commitments to the field and to its future.

James Young recalls the German family who rescued him in 1976 when, as a young backpacker, he was haplessly without lodging on a cold, wet night. Bonding through their common interests in World War II, they took him to a small village on the Baltic sea where he learned the tragic fate of the S.S. Cap Arcona and two other ships. Filled with 8,000 concentration camp inmates, the ships were mistakenly bombed by the Royal Air Force, assuming they carried Nazi troops. Local villagers had rescued survivors and then collected bodies for burial as they washed up from the sea, but neither the dead nor the villagers' involvement had been honored. Only oral tradition recorded the whole story. A simple stone monument "that concealed much more than it remembered, would nonetheless be a revelation to me, my first Holocaust memorial epiphany" (64). Young's lifetime study of memory and memorialization has followed. 
For social historian Debórah Dwork there was a direct connection-her aunt was the sole family member remaining in Lodz when the Nazis invaded. She asked why there was only limited scholarly explorations of daily life like her aunt had experienced, especially of the lives of Jewish children. Her research for Children with a Star (1991), including her use of primary sources, was considered a new dimension in Holocaust studies at that time. However, for Dwork these questions continue to serve as a "compass" for how she approaches both the history and its teaching (75). What will we remember of how it happened and how it was experienced, of people's decisions and choices? What can we learn that will enable us to decode our world and have it shape our understandings and responses?

Other contributors cite formative connections as well. Alex Alvarez grapples with a difficult history when discussing his German family members, including a grandfather who served in the German Air Force during World War II. Wolf Gruner, growing up behind the Iron Curtain in East Germany, recalls being kicked out of school in tenth grade for his "fascist" ideas. Jonathan Petropoulos was raised with stories of his Greek father's childhood during the Occupation. All speak of early and complex imprints. For Robert Ventresca and Robert Erickson, it was necessary to confront challenges to idealized views of the past. Erickson, growing up in a family of Lutheran pastors, describes his initial immersion in intellectual history:

I expected to find German professors-heirs to the best university system in the world at that time - smart enough to see the flaws in Nazi ideology, even if not all would take the risk of open opposition. I expected to find German professors of theology - heirs to the Protestant Reformation and the strongest theological tradition of their day - morally and spiritually acute enough to reject Nazism, even if they were not ready to follow the path of a dissenting Dietrich Bonhoeffer (145).

As he grew to see insidious roots of antisemitism within the Christian tradition, his research focused on church leaders' betrayal of these ideals and the complicity of formerly idealized religious institutions with Nazism.

Ventresca, noted biographer of Pope Pius XII, writes that explaining the Pope's silence during the Nazi era remains one of the most significant challenges for Holocaust studies in the $21^{\text {st }}$ century:

Questions about Pope Pius XII's spiritual authority and political influence in a time of war and genocide haunt me as a Catholic and motivate me as a historian... [It is] a vast and complex task that requires untangling, to the extent possible, the snarled threads of theology, religious identity, culture and politics (116).

While Ventresca was raised in a post-Nostra Aetate world, in his early education he learned little about these difficult questions. His subsequent work grapples with 
them. Doubting that opening the Vatican archives will lead either to Pius' vilification or exoneration for his wartime actions, Ventresca is concerned that any oversimplification will make it possible to avoid hard questions:

Given the pope's spiritual authority, were prudence and impartiality in a time of extreme humanitarian crises consistent with the judgement and action expected, even demanded, of the Vicar of Christ? To my thinking, the answer to those questions is a resounding no. As a historian who is also a practicing Catholic, I cannot shy away from my responsibility (121).

Rittner and Roth have provided us with a provocative examination of contemporary Holocaust studies, showing both doors which have opened and those yet to be unlocked. All thirteen scholars raise current concerns that demand ongoing historical probing and further application to a world still fraught with racism, immorality, and genocide. Perhaps what is most memorable about this unique anthology is the contributors' self-reflections and discussions of how their personal experiences brought them to their research, and how their views have evolved through time. They encourage us, whether student or scholar, to be aware of our own lenses and our own journeys. Such deep connections will inevitably advance the field in both breadth and depth. 